\title{
MODEL PENDEKATAN PENINGKATAN MUTU PENDIDIKAN AGAMA ISLAM
}

\author{
Zaedun Na'im \\ Sekolah Tinggi Agama Islam Ma'had Aly Al Hikam Malang \\ zaidun_naim@yahoo.com
}

\begin{abstract}
Abstraksi
Salah satu permasalahan pendidikan yang dihadapi oleh bangsa Indonesia adalah rendahnya mutu pendidikan pada setiap jenjang dan satuan pendidikan, khususnya pendidikan dasar dan menengah. Padahal kebijakan pemerintah untuk meningkatkan mutu lembaga pendidikan dilakukan berbagai cara.

Masalah pendidikan agama merupakan masalah yang kompleks dan membutuhkan kerja keras dari semua elemen yang terkait dengannya. Pendidikan agama Islam memiliki karakteristik tersendiri yang berbeda dengan mata pelajaran lainnya. Istilah pendidikan yang melekat pada nama pelajaran ini menuntut guru sebagai pelaksana, tidak saja berusaha untuk mentransfer pengetahuan, akan tetapi lebih dari itu ia harus berusaha agar pengetahuan yang disampaikannya dapat terinternalisasi dalam diri para siswa

Oleh karenanya perlu kiranya mencari solusi atau jalan keluar untuk peningkatan mutu pendidikan di negeri ini lebih-lebih pada pendidikan agama Islam, hal ini bukan tidak ada alasan karena kualitas pendidikan di lembaga sekolah sangat bervariasi dan sebagaian besar sangat memprihatinkan, contohnya saja di lembaga Madrasah

Model pendekatan peningkatan mutu pendidikan agama Islam antara lain Preliminary control, concurrent control, rework control dan damage control. Dari ke empat model pendekatan mutu pendidikan ini lebih ringkasnya mencakup input, transformasi (proses), output, dan stakeholder value ( nilai pengguna)
\end{abstract}

Kata Kunci: model pendekatan, peningkatan mutu, pendidikan agama Islam 


\section{BAB I \\ PENDAHULUAN}

A. Latar belakang masalah

Salah satu permasalahan pendidikan yang dihadapi oleh bangsa Indonesia adalah rendahnya mutu pendidikan pada setiap jenjang dan satuan pendidikan, khususnya pendidikan dasar dan menengah ${ }^{1}$. Padahal kebijakan pemerintah untuk meningkatkan mutu lembaga pendidikan dilakukan berbagai cara. Yaitu dengan dengan meningkatkan mutu tenaga akademik secara berkelanjutan, penataan program studi, peningkatan proporsi murid bidang sains dan keteknikan, pengembangan kurikulum yang fleksibel dan terkendali, peningkatan mutu penelitian dan pengabdian kepada masyarakat, pengadaan sarana/prasarana dan fasilitas penunjang, peningkatan kerja sama dengan pemerintah daerah, dunia usaha, kalangan industri dan lembaga dalam dan luar negeri ${ }^{2}$

Berdasarkan masalah ini, maka berbagai pihak mempertanyakan apa yang salah dalam penyelenggaraan pendidikan kita? dari berbagai pengamatan dan analisis, sedikitnya ada tiga faktor yang menyebabkan mutu pendidikan tidak mengalami peningkatan secara merata. Faktor Pertama, Kebijakan dan penyelenggaraan pendidikan nasional menggunakan pendekatan education production function atau inputoutput analisis yang tidak dilaksanakan secara konsekuen

Pendekatan ini melihat bahwa lembaga pendidikan berfungsi sebagai pusat produksi yang diperlukan dalam kegiatan produksi tersebut, maka lembaga ini akan menghasilkan output yang dikehendaki. Faktor Kedua, penyelenggaraan pendidikan nasional dilakukan secara birokratik-sentralistik, sehingga menempatkan sekolah sebagai pemnyelenggara pendidikan tergantung pada keputusan birokrasi panjang dan kadang-kadang kebijakan yang dikeluarkan tidak sesuai dengan kondisi sekolah setempat. Faktor Ketiga, peran serta masyarakat, khususnya orang tua siswa dalam penyelenggaraan pendidikan selama ini pada umumnya lebih banyak bersifat dukungan

\footnotetext{
${ }^{1}$ Abdul Rachman Shaleh. Madrasah dan Pendidikan Anak Bangsa. (Jakarta:PT RajaGrafindo Persada, 2006) hlm 249

${ }^{2}$ Veitsal Rivai dan Sylviana Murni. Education Management ( Jakarta; PT Rajagrafindo, 2009) hlm 714
} 
input (dana), bukan pada proses pendidikan (pengambilan keputusan, monitoring, evaluasi, dan akuntabilitas) ${ }^{3}$

Jika dikaitkan dengan tujuan pendidikan nasional, pendidikan agama merupakan salah satu mata pelajaran yang diharapkan dapat memberikan kontribusi yang signifikan bagi pencapaian tujuan pendidikan nasional. Salah satu tujuan utama pendidikan nasional seperti tercantum dalam UUSPN adalah pembentukan manusia yang bertaqwa dan berbudi pekerti luhur.

Dengan dasar pemikiran di atas, maka masalah pendidikan agama merupakan masalah yang kompleks dan membutuhkan kerja keras dari semua elemen yang terkait dengannya. Pendidikan agama Islam memiliki karakteristik tersendiri yang berbeda dengan mata pelajaran lainnya. Istilah pendidikan yang melekat pada nama pelajaran ini menuntut guru sebagai pelaksana, tidak saja berusaha untuk mentransfer pengetahuan, akan tetapi lebih dari itu ia harus berusaha agar pengetahuan yang disampaikannya dapat terinternalisasi dalam diri para siswa ${ }^{4}$

Oleh karenanya perlu kiranya mencari solusi atau jalan keluar untuk peningkatan mutu pendidikan di negeri ini lebih-lebih pada pendidikan agama Islam, hal ini bukan tidak ada alasan karena kualitas pendidikan di lembaga sekolah sangat bervariasi dan sebagaian besar sangat memprihatinkan, contohnya saja di lembaga Madrasah.

Di Madrasah, ini dapat diamati dari berbagai aspek, baik yang berhubungan dengan instrumental input, seperti kurikulum, tenaga pengajar, bahan ajar maupun yang berkaitan dengan environmental, seperti kondisi lingkungan fisik dan administrasi sekolah, aspek-aspek yang terkait dengan proses, seperti proses pembelajaran, dan saranaprasana yang diperlukan, maupun yang terkait dengan output dan outcome, seperti lulusan dan keterserapannya oleh pasar tenaga kerja ${ }^{5}$

\footnotetext{
${ }^{3}$ Abdul Rachman Shaleh. Op.cit hlm 249

4 Tim Pengembang ilmu Pendidikan FIP-UPI. Ilmu dan Aplikasi Pendidikan. (Bandung: PT Imperial Bhakti utama, 2007) hlm 1

${ }^{5}$ Abdul Rachman Shaleh op.cit hlm XIII
} 


\section{BAB II \\ PEMBAHASAN}

1. Konsep Dasar manajemen peningkatan Mutu Pendidikan

Manajemen peningkatan mutu pendidikan diperlukan sekolah karena beberapa hal, antara lain:

a. Sekolah ingin mengetahui kekuatan, kelemahan, peluang, dan ancaman bagi dirinya sehingga dia dapat mengoptimalkan pemanfatan sumber daya yang tersedia untuk memajukan sekolahnya

b. Sekolah ingin mengetahui kebutuhan lembaganya, khususnya input pendidikan yang akan dikembangkan dan kebutuhan peserta didik

c. Pengambilan keputusan yang dilakukan oleh sekolah lebih cocok untuk memenuhi kebutuhan sekolah karena pihak sekolah yang paling tahu apa yang terbaik bagi sekolahnya

d. Penggunaan sumber daya pendidikan lebih efisien dana efektif bilamana dikontrol oleh masyarakat dalam pengambilan keputusan sekolah menciptakan transparansi dan demokrasi yang sehat ${ }^{6}$

Pada dasarnya mutu pendidikan berkaitan dengan pencapaian tujuan pendidikan dan kompetensi lulusan yang telah ditetapkan oleh institusi pendidikan di dalam rencana strategisnya atau kesesuaian tujuan dan kompetensi dengan standar yang telah ditetapkan. Sedangkan penjaminan mutu berkaitan dengan keseluruhan aktivitas dalam berbagai bagian dari suatu system untuk memastikan bahwa mutu produk atau layanan yang dihasilkan itu konsisten dan sesuai dengan yang direncanakan atau ditetapkan ${ }^{7}$

Konsep manajemen mutu pendidikan merupakan sebuah konsep yang berasal dari Total Quality Management (TQM). TQM pertama kali diperkenalkan pada tahun 1920 an oleh Edward Deming di Jepang. Deming adalah seorang warga Amerika yang menjadi salah satu konsultan perusahaan di Jepang. Konsep TQM pada awalnya berkembang dari pemikiran untuk mewujudkan produk yang bermutu sampai pada akhirnya meliputi semua aspek dalam organisasi ${ }^{8}$

\footnotetext{
${ }^{6}$ Abdul Rachman Shaleh. Op.cit hlm 250

${ }^{7}$ Buchari Alma \& Ratih Hurriyati. Manajemen Corporate dan strategi pemasaran jasa pendidikan. (bandung: Alfabeta, 2008) hlm 76

${ }^{8}$ Tim Dosen Administrasi pendidikan UPI. Manajemen Pendidikan. (Bandung:

Alfabeta, 2009) hlm 290
} 
Total Quality management (TQM) dapat dipilih sebagai suatu pendekatan dalam pengendalian mutu pendidikan. Dalam pendekatan ini terdapat empat komponen dasar pengendalian mutu, yaitu: input, transformasi atau proses, output, dan nilai bagi stakeholders. ${ }^{9}$

Total Quality Management akan suskes diterapkan pada lembaga pendidikan jika manajer pendidikan melakukan hal hal berikut:

1) Pahami: filosofi, visi, misi, aksi, kebutuhan pelanggan, dan keunikan karyawan

2) Ciptakan: proses yang efisien, budaya kerja yang kondusif, dan tim kerja yang solid

3) Galakkan: pencatatan data, usaha perbaikan, dan semangat kerja;

4) Kembangkan: diri sendiri, bawahan, dan rekanan

5) Dapatkan; kesamaan persepsi, komitmen atasan, teman selevel, dan bawahan

6) Terapkan: gaya kepemimpinan partisipatif

Sebaiknya manajer pendidikan tidak melakukan:

a) Berpikir negatif, berperilaku "bos"

b) Statis

c) Resisten terhadap perubahan

d) Mengabaikan pendapat/kritik

e) Beranggapan hasil kerja adalah hasil anda sendiri

f) Sangat subjektif

g) Tidak adil, dan

h) Tidak jujur ${ }^{10}$

Banyak masalah mutu di hadapi dalam dunia pendidikan, seperti mutu lulusan, mutu pengajaran, bimbingan, dan latihan dari guru, serta profesionalisme dan kinerja guru. Mutu-mutu tersebut terkait dengan mutu manajerial para pemimpin pendidikan, keterbatasan dana, sarana dan prasarana, fasilitas pendidikan, media, sumber belajar, alat dan bahan latihan, iklim sekolah, lingkungan pendidikan, serta dukungan dari pihak-pihak yang terkait dengan pendidikan. Semua kelemahan mutu dari komponen-komponen pendidikan tersebut berujung pada rendahnya mutu lulusan

${ }^{9}$ Buchari Alma \& Ratih Hurriyati Op.Cit hlm 78

${ }^{10}$ Husaini Usman. Manajemen teori praktik dan riset pendidikan. (Jakarta:Bumi Aksara, 2008) hlm554 
Mutu lulusan yang rendah dapat menimbulkan berbagai masalah, seperti lulusan tidak dapat melanjutkan studi, tidak dapat menyelesaikan studinya pada jenjang yang lebih tinggi, tidak dapat bekerja/tidak diterima di dunia kerja, diterima bekerja, tetapi tidak berprestasi, tidak dapat mengikuti perkembangan masyarakat, dan tidak produktif. Lulusan yang tidak produktif akan menjadi beban masyarakat, menambah biaya kehidupan dan kesejahteraan masyarakat, serta memungkinkan menjadi warga yang tersisih dari masyarakat. ${ }^{11}$

Manajemen peningkatan mutu pendidikan memiliki karakteristik yang perlu dipahami oleh sekolah yang akan menerapkannya. Dengan kata lain, jika sekolah ingin sukses dalam menerapkannya, maka sejumlah karaktersitik berikut ini perlu dimiliki, yaitu karakteristik dari sekolah efektif ( effective school). Manajemen peningkatan mutu pendidikan merupakan wadah/kerangkanya, maka sekolah efektif merupakan isinya. Oleh karena itu, karakteristik berikut memuat secara inklusif elemen-elemen sekolah efektif, yang dikategorikan menjadi input, proses, dan output ${ }^{12}$

a. Input

1) Kebijakan mutu dan harapan

2) Sumber daya ( kesediaan masyarakat)

3) Berorientasi siswa

4) Manajemen ( Pembagian tugas, perencanaan, kendali mutu, efisiensi)

b. Proses

1) Pembelajaran, berorientasi:

a) Learning to know

b) Learning to do

c) Learning to be

d) Learning to live together

2) Kepemimpinan yang kuat/demokratis

a) Kemampuan manajerial

b) Kemampuan memobilisasi

c) Memiliki otonomi luas

${ }^{11}$ Nanang Hanafiah \& Cucu Suhana. Konsep Strategi Pembelajaran. (Bandung: PT Refika Aditama, 2009) hlm 92

${ }^{12}$ Abdul ranchman Shaleh. Op.Cit hlm 252

105 Model Pendekatan Peningkatan Mutu Pendidikan Agama Islam 
3) Lingkungan: aman, nyaman, manusiawi

4) Pengelolaan tenaga yang efektif

a) Perencanaan

b) Pengembangan

c) Penilaian

d) Imbal jasa

5) Memilki budaya mutu ( kerja sama, merasa memiliki, mau berubah, mau meningkatkan diri terbuka)

6) Tim kerja ( kompak, cerdas, dinamis)

7) Partisipasi masyarakat tinggi

8) Memilki akuntabilitas.

a) Laporan prestasi

b) Respons / tanggapan masyarakat

c. Output

1) Prestasi akdemik

NEM, STTB, Taraf serap, Lomba karya ilmiah,Lomba keagamaan, Prestasi non kademik, Olahraga, Kerapian/ketertiban, Kepramukaan, Kebersihan, Toleransi, Ketulusan, Kesenian, Disiplin, Kerajinan, Solidaritas, Silaturahmi, Dan lain-lain 
PERHATIKAN RUANG LINGKUP MUTU DIBAWAH INI:

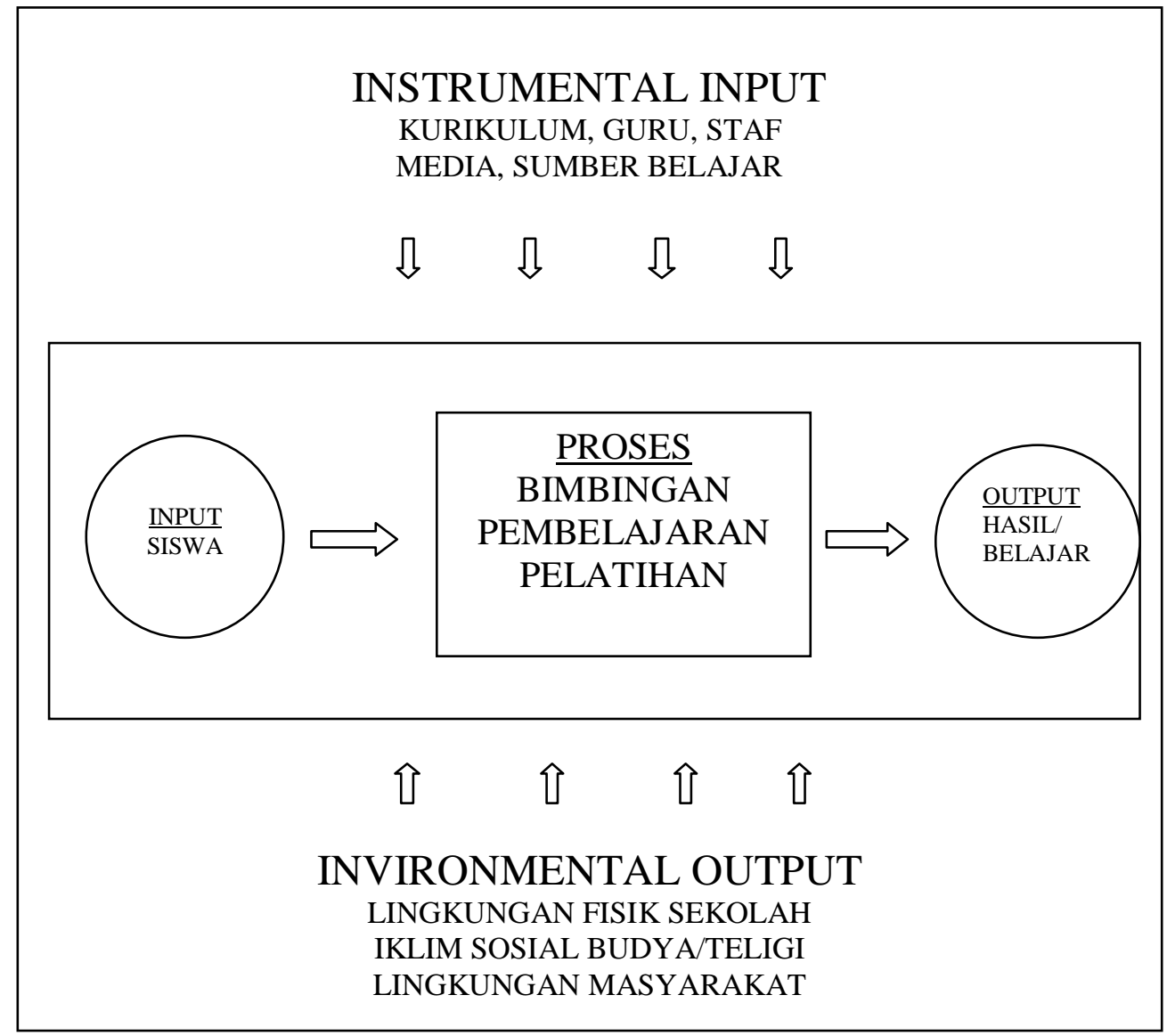

Sedangkan prinsip manajemen mutu pendidikan meliputi beberapa aspek antara lain: Perencanaan, Pelaksanaan, Pengendalian, Pengawasan, Pengukuran hasil, Pelayanan masyarakat, dan Pembinaan lingkungan. ${ }^{13}$

Secara ringkas mengenai manajemen mutu pendidikan sebagai berikut: PENINGKATAN MUTU PENDIDIKAN

1) Dilaksanakan pada level sekolah

2) Diperlukan kepemimpinan yang baik

3) Didasarkan atas data dan fakta ( melalui school review)

4) Dilaksanakan secara terus menerus berkelanjutan

${ }^{13}$ Abdul ranchman Shaleh. Op.Cit hlm 253-256

107| Model Pendekatan Peningkatan Mutu Pendidikan Agama Islam 
5) Melibatkan unsur sekolah

6) Berorientasi tujuan dan masa depan (visi dan misi)

7) Memberikan kepuasan kepada siswa, orangtua, dan masyarakat (stakeholders)

LANGKAH-LANGKAH

1) Upaya pengendalian proses (teknik-administrasi)

2) Melibatkan diagnose dan tindakan

3) Memerlukan partisipasi semua pihak (intern-ekstern) KOMPONEN DASAR PROGRAM MUTU

1) Adanya rencana/program

2) Memahami visi, misi, stretegi, dan tujuan

3) Pemahaman konsep

4) Komitmen terhadap perubahan PRINSIP PENINGKATAN MUTU

1) Kepemimpinan profesional

2) Membantu siswa mengembangkan kemampuan

3) Kerja sama, teamwork, dan akuntabilitas

4) Komitmen pada perubahan

5) Sistem pengukuran

6) Program berkelanjutan

7) Keterlibatan peran masyarakat

8) Pelatihan $\operatorname{staf}^{14}$

Oleh karena itu dalam rangka mengimplementasikan konsep manajeman peningkatan mutu di sekolah, maka melalui partisipasi aktif dan dinamis dari orangtua, siswa, guru dan staf lainnya termasuk institusi yang memiliki kepedulian terhadap pendidikan sekolah harus melakukan tahapan kegiatan sebagai berikut

a. Penyusunan basis data dan profil sekolah lebih presentatif, akurat, valid dan sistematis menyangkut berbagai aspek akademis, administratif (siswa, guru, staf), dan keuangan

b. Melakukan evaluasi diri (self assessment) untuk menganalisis kekuatan dan kelemahan mengenai sumber daya sekolah, personal sekolah, kinerja dalam mengembangkan dan mencapai target kurikulum dan hasil-hasil yang dicapai siswa berkaitan dengan aspek-aspek intelektual dan keterampilan, maupun aspek lainnya

${ }^{14}$ Abdul ranchman Shaleh. Op.Cit hlm 260 
c. Berdasarkan analisis tersebut sekolah harus mengidentifikasikan kebutuhan sekolah dan merumuskan visi, misi, dan tujuan dalam rangka menyajikan pendidikan yang berkualitas bagi siswanya sesuai dengan konsep pembangunan pendidikan nasional yang akan dicapai.

d. Berangkat dari visi, misi dan tujuan peningkatan mutu tersebut sekolah bersama-sama dengan masyarakatnya merencanakan dan menyusun program jangka panjang atau jangka pendek ( tahunan termasuk anggarannya) ${ }^{15}$

Mutu pendidikan juga dipengaruhi oleh faktor-faktor internal dan eksternal mutu proses dan hasil belajar mengajar di kelas. Adapun faktor internal berupa: faktor psikologis, sosiologis dan fisiologis yang ada pada diri siswa dan guru sebagai pelajar dan pembelajar. Sedangkan yang termasuk faktor eksternal ialah semua faktor-faktor yang mempengaruhi proses hasil belajar mengajar di kelas selain faktor yang bersumber dari faktor guru dan siswa, yakni berupa faktor masukan lingkungan, peralatan, dana lain-lain ${ }^{16}$

Dalam konteks sistem pembelajaran, agaknya titik lemah pendidikan agama lebih terletak pada komponen metodologinya. Kelemahan tersebut dapat diidentifikasi sebagai berikut:

(1) Kurang bisa mengubah pengetahuan agama yang kognitif menjadi "makna" dan "nilai" atau kurang mendorong penjiwaan terhadap nilai-nilai keagamaan yang perlu dinternalisasikan dalam peserta didik; (2) kurang dapat berjalan bersama dan bekerjasama dengan program-program pendidikan non-agama; (3) kurang mempunyai relevansi terhadap perubahan sosial yang terjadi di masyarakat atau kurang ilustrasi kontesk sosial budaya, dan/atau bersifat statis kontekstual dan lepas dari sejarah, sehingga peserta didik

${ }^{15}$ Rusman. Manajemen kurikulum. (bandung:PT Rajagrafindo Persada, 2009) hlm 556

${ }^{16}$ Abdul hadis dan Nurhayati. Manajemen Mutu Pendidkan ( Bandung;

Alfabeta,2010) hlm 100

109| Model Pendekatan Peningkatan Mutu Pendidikan Agama Islam 
kurang menghayati nilai-nilai agama sebagai nilai yang hidup dalam keseharian ${ }^{17}$

Peningkatan mutu pendidikan di sekolah akan terjadi bilamana ada kemauan dan prakarsa dari bawah, dimana kepala sekolah, guru kelas, orangtua siswa, komite sekolah berkemauan dan bekerja keras berupaya mengembangkan program-program peningkatan mutu pendidikan di sekolahnya ${ }^{18}$

Dengan demikian peningkatan mutu pendidikan bisa terealisasi tidak lepas dari peran serta dan kerjasama antar semua elemen yang ada di lembaga sekolah seperti kepala sekolah, guru, orang tua siswa dan komite sekolah karena semua elemen di sekolah ini menjadi bagian satu kesatuan yang tidak bisa di lepaskan dari upaya peningkatan mutu pendidikan

2. Model pendekatan peningkatan mutu pendidikan agama Islam

Untuk memberi gambaran tentang bagaimana sasaran mutu pendidikan agama Islam di lembaga pendidikan, penulis uraikan tujuan dari pendidikan agama Islam sebagai berikut

Tujuan pendidikan agama di lembaga-lembaga pendidikan formal di indonesia dapat dibagi menjadi dua macam, yaitu: (1) tujuan umum dan (2) tujuan khusus

a. Tujuan umum pendidikan agama

Tujuan umum pendidikan agama adalah membimbing peserta didik agar mereka menjadi muslim sejati, beriman teguh, beramal shaleh dan berakhlak mulia serta berguna bagi masyarakat, agaman dan negara

b. Tujuan khusus pendidikan agama

Tujuan khusus pendidikan agama adalah tujuan pendidikan agama pada setiap tahap/tingkat yang dilalui, seperti tujuan pendidikan agama untuk SD berbeda dengan tujuan pendidikan agama sekolah menengah, dan berbeda pula dengan perguruan tinggi

1) Tingkat sekolah dasar (SD)

Murid bergairah beribadat, murid mampu membaca al-Qur'an, Penanaman rasa agama kepada murid, menanamkan rasa cinta kepada Allah dan Rasul-Nya, memperkenalkan ajaran Islam yang

17 Muhaimin. Pengembangan Kurikulum Pendidikan Agama Islam. ( Jakarta: PT RajaGrafindo Persada, 2010) hlm 27

${ }^{18}$ Ibrahim Bafadal. Manajemen Peningkatan Mutu Sekolah Dasar (Jakarta: PT Bumi Aksara, 2006) hlm 36 
bersifat global, seprti rukun Islam, rukun iman, dan lain-lain, membiasakan anak-anak berakhlak mulia, dan melatih anakanak untuk mempraktikkan ibadah yang bersifat praktis-praktis, seperti sholat, puasa dan lain-lain, membiasakan contoh teladan yang baik.

2) Tingkat sekolah menengah pertama (SMP)

Memberikan ilmu pengetahuan agama Islam, memberikan pengertian tentang agama Islam yang sesuai dengan tingkat kecerdasannya, memupuk jiwa agama, membimbing anak agar mereka beramal shaleh dan berakhlak mulia.

3) Tingkat sekolah menengah atas (SMA)

Siswa memahami dan menghayati ajaran Islam sehingga beriman dengan mengetahui dalil naqilnya, tekun sholat dengan menghayati hikmahnya, tekun membaca al-Qur'an dengan memahami ayat-ayat tertentu, terbiasa berdo'a, mensyukuri nikmat, dan beramal shaleh serta membangun kehidupan berbangsa dan bernegara, siswa bertakwa dan bersyukur kepada Allah, siswa hidup rukun dalam bermasyarakat, bernegara dan berbangsa

4) Tingkat universitas

Terbentuknya sarjana muslim yang takwa kepada Allah, tertanamnya akidah islamiyah pada setiap mahasiswa, terwujudnya mahasiswa yang taat beribadah dan berakhlak

Tujuan pendidikan agama tersebut diatas, juga disebut tujuan kurikuler, disesuaikan dengan kurikulum pendidikan agama mulai SD sampai dengan tingkat universitas. ${ }^{19}$

Sementara itu dalam melaksanakan pendidikan agama, perlu diperhatikan adanya beberapa faktor yang mempengaruhinya. Faktorfaktor pendidikan agama tersebut ikut menentukan berhasil atau tidaknya pendidikan agama

Faktor-faktor pendidikan agama dapat dikelompokkan menjadi lima macam. Antara faktor yang satu dengan yang lainnya mempunyai hubungan yang erat sekali. Adapun kelima faktor tersebut adalah : (1)

${ }^{19}$ Zuhairini dan Abdul Ghofir. Metodologi pembelajaran Pendidikan Agama Islam ( Malang: UM Pres, 2004) hlm 24-26

111| Model Pendekatan Peningkatan Mutu Pendidikan Agama Islam 
peserta didik, (2) pendidik, (3) tujuan pendidikan, (4) alat-alat pendidikan, dan (5) lingkungan / illieu. $^{20}$

Kelima faktor tersebut digambarkan dalam bentuk bagan segi lima di bawah ini

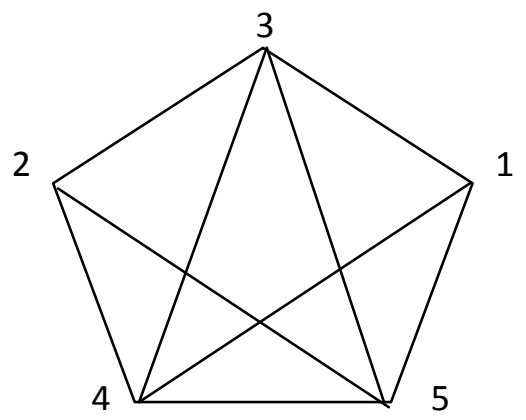

Gambar diatas menunjukkan adanya hubungan interelasi yang erat antara faktor yang satu dengan faktor yang lainnya. Faktor-faktor tersebut ikut menetukan berhasil atau tidaknya suatu pendidikan yang dilaksanakan.

Untuk melaksanakan pendidikan agama Islam yang berhasil perlu dilakukan pendidikan agama yang terpadu. Keterpaduan yang dimaksud adalah: keterpaduan tujuan, keterpaduan materi, keterpaduan proses.

a. Keterpaduan tujuan

berarti pencapaian tujuan pendidikan merupakan tanggung jawab semua pemangku kepentingan (stakeholders) pendidikan, yaitu pemerintah, kepala sekolah, guru, orang tua siswa, dan masyarakat.

b. Keterpaduan materi

ialah keterpaduan isi kurikulum yang digunakan atau materi pelajaran. Semua materi pelajaran yang dipelajari siswa handaknya saling memiliki keterkaitan antara satu mata pelajaran dengan mata pelajaran yang lainnya. Pengikat keterpaduan tersebut adalah tujuan pendidikan keimanan dan ketakwaan. Jadi selain tujuan mata pelajaran itu sendiri, hendaknya semua bahan ajar mengarah kepada terbentuknya manusia beriman dan bertaqwa.

c. Keterpaduan proses,

berarti para pendidik hendaknya menyadari bahwa semua kegiatan pendidikan sekurang-kurangnya tidak berlawanan dengan tujuan

${ }^{20}$ Zuhairini dan Abdul Ghofir Op.Cit hlm 13 
pendidikan keimanan dan ketakwaan, bahkan dikehendaki semua kegiatan pendidikan membantu tercapainya siswa yang beriman dan bertakwa. $^{21}$

Dalam model pendekatan peningkatan mutu pendidikan agama Islam ini, penulis menggunakan model pendekatan mutu pendidikan secara umum, antara lain:

1) Preliminary control

Preliminary control bersifat preventif untuk menghindari mutu yang tidak diinginkan dan proaktif untuk mencapai mutu yang semakin meningkat. Preliminary control ini difokuskan pada input atau sumber penyebabnya. Dengan memperbaiki input berarti melakukan pengendalian terhadap komponen transformasi, output, dan nilai bagi stakeholders (pengguna lulusan).

Ini mencari sumber-sumber penyebab kurang optimalnya pendidikan agama sehingga dari temuan ini bisa dipelajari dan dicari solusinya

2) Concurrent Control

Concurrent control dilakukan terhadap kegiatan yang telah dilakukan dan menggambarkan pengendalian operasional. Focus concurrent control ini pada transformasi atau proses.

Untuk mencapai proses penerimaan pendidikan agama yang optimal diperlukan kontrol yang efektif sehingga hasil yang diinginkan dari pendidikan agama bisa tercapai

3) Rework Control

Rework Control dilakukan apabila preliminary control dan concurrent control mengalami kegagalan sehingga perlu rework terhadap defect (cacat) dan output yang tidak sesuai dengan target. Pendekatan perbaikan mutu ini memerlukan sumber daya yang relative besar. Fokus rework control pada komponen output

Ketika target yang ingin dicapai dalam mutu pendidikan agama belum tercapai pada hasil belajar anak didik, maka perlu adanya evaluasi terhadap komponen atau hal-hal yang mempengaruhi belajar anak didik dalam menerima pendidikan agama

${ }^{21}$ A. Tafsir dalam www.scribd.com/...STRATEGI-MENINGKATKAN-MUTU-PAI -

113 Model Pendekatan Peningkatan Mutu Pendidikan Agama Islam 
4) Demage Control

Demage control dilakukan untuk menimimalkan dampak negative dari tidak tercapainya target nilai bagi stakeholders. Fokus damage control ini pada komponen nilai bagi stakeholders

Dalam hal ini lebih menekankan pada evaluasi terhadap kinerja stakeholder ( kepala sekolah) dalam pencapaian target-target yang belum terealisasi dalam pendidikan agama pada anak didik.

Secara skematis pendekatan atau model pengendalian mutu dalam rangka penjaminan mutu pendidikan disaji sebagai berikut:

Informasi mengenai nilai yang disampaikan dan kebutuhan pelanggan yang belum terpenuhi

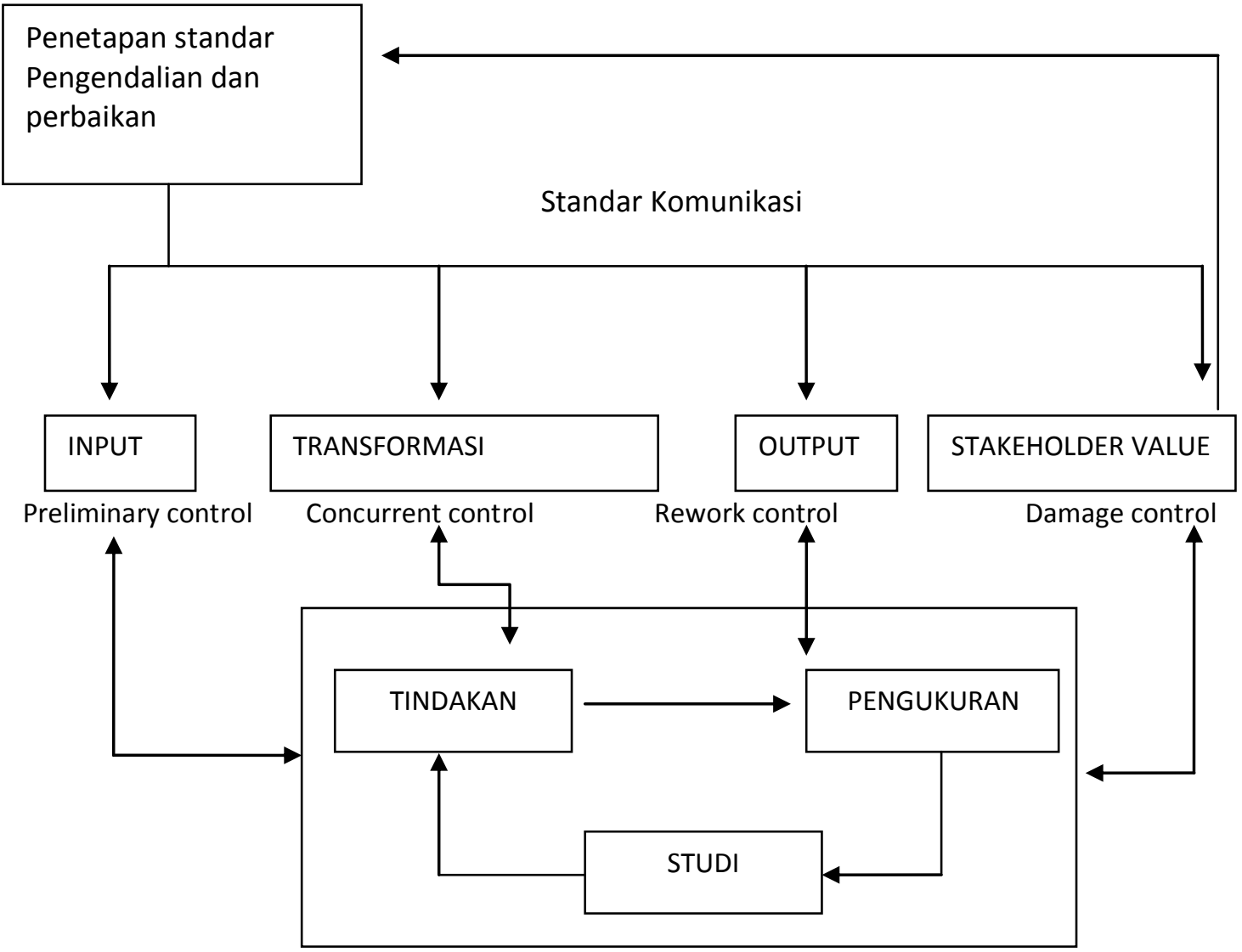

Dalam proses pengendalian mutu dalam rangka penjaminan mutu pendidikan yang menurut penulis juga bisa diterapkan dalam 
pendidikan agama Islam ini mengarah pada pengendalian mutu berbasis plan, do, check, action (PDCA). Proses ini sesuai dengan model TQM sebagai model pengendalian mutu yang sering digunakan di lembaga pendidikan / sekolah. Proses pengendalian mutu berbasis PDCA ini akan menghasilkan perbaikan berkelanjutan atas mutu pendidikan termasuk juga mutu pendidikan agama Islam

Pada tahap check terdapat titik-titik kendali mutu, di mana setiap penyelenggaraan proses pendidikan pada tiap unit kerja di sekolah harus mengevaluasi hasil pelaksanaan tugasnya dengan standar atau sasaran mutu yang telah ditetapkan. Penetapan titiktitik kendali mutu harus dilakukan pada setiap satuan kegiatan untuk setiap butir mutu. Contoh; pelaksanaan tes formatif yang dilakukan pada akhir setiap pokok bahasan merupakan titik kendali mutu dalam proses pembelajaran. Tes formatif dilakukan untuk apakah standar mutu pembelajaran sebagaimana dirumuskan dalam RPP telah tercapai atau belum ${ }^{22}$

Dengan pendekatan-pendekatan peningkatan mutu pendidikan agama Islam di atas kiranya sangat membantu dalam proses untuk mencapai hasil yang optimal dalam peningkatan mutu, karena dalam pendekatan tersebut berisi evaluasi semua elemen elemen sekolah yakni input, proses, output dan stakeholder

Sedangkan dalam model penjamin mutu pendidikan agama Islam, antara lain: ${ }^{23}$

\section{a) School review}

Model ini merupakan sebuah proses yang merupakan seluruh komponen madrasah/sekolah yang bekerja sama khususnya dengan orang tua dan tenaga profesional untuk mengevaluasi efektifitas pendidikan agama islam serta mutu lulusan.

School review dilakukan untuk menjawab pertanyaan-pertanyaan berikut: (1) apakah yang dicapai madrasah/sekolah sesuai dengan harapan orang tua siswa dan siswa sendiri? (2) bagaimana prestasi yang telah dicapai para peserta didik? (3) foktor apa yang menghambat upaya untuk meningkatkan mutu? (4) apakah foktorfoktor pendukung yang dimiliki pendidikan Agama Islam

${ }^{22}$ Rusman op.cit hlm 561

23 www.kabar-pendidikan.blogspot.com diakses 28 Juni 2011

115 Model Pendekatan Peningkatan Mutu Pendidikan Agama Islam 


\section{b) Benchmarking}

Pendekatan ini merupakan salah satu kegiatan untuk menetapkan standar dan target yang akan dicapai dalam suatu periode tertentu. Benchmaking dapat dipastikan untuk individu, kelompok atuapun lembaga. Standar dapat ditentukan berdasarkan keadaan realitas yang ada di madrasah/sekolah, misalnya prestasi yang diraih siswa yang baik prilakunya dan yang sedikit nakal namun cerdas (internal benchmaking), maupun membandingkan standar kualitas dari madrasah/sekolah lain yang lebih baik (exsternal benchmaking). Tiga pertanyaan mendasar yang akan dijawab oleh benchmaking ini diantaranya; (1) seberapa besar kondiri kita? (2) harus menjadi seberapa baik? (3) bagaimana cara untuk mencapai yang baik tersebut.?

Sedangkan langkah-langkah yang dilaksanakan adalah menentukan fokus, menentukan aspek, variabel atau indikator, menentukan standar, menentukan gep (kesenjangan) yang terjadi, membandingkan standar dengan kondisi kita, merencanakan target untuk mencapai standar, merumuskan sasaran-sasaran program untuk mencapai target.

\section{c) Quality assurance}

Quality assurance merupakan suatu teknik untuk menentukan bahwa proses pendidikan telah berlangsung sebagaimana rencana awal dan yang seharusnya. Dengan teknik ini akan dapat dideteksi adanya deviasi (penyimpangan) yang terjadi pada proses. Teknik ini menekankan pada proses monitoring yang berkesinambungan dan melembaga, yang menjadi subsistem madrasah/sekolah.

Implikasi dari proses quality assurance akan menghasilkan informasi sebagai berikut; (1) merupakan umpan balik (fidback) bagi madrasah/sekolah; (2) memberikan jaminan bagi orang tua siswa bahwa madrasah/sekolah senantiasa memberikan pelayanan terbaik bagi siswa.

Untuk melaksanakan quality assurance, maka lembaga pendidikan harus menekankan pada kualitas hasil belajar, hasil kerja siswa yang dimonitoring secara terus menerus. Informasi dari lembaga dikumpulkan dan dianalisis untuk memperbaiki proses yang berjalan, dan semua pihak dari mulai kepala madrasah, guru, pegawai administrasi, dan juga orang tua siswa harus memiliki komitmen untuk bersama-sama mengevaluasi kondisi madrasah/sekolah yang kritis dan berupaya untuk memperbaikinya. 


\section{d) Quality control}

Qaulity control adalah suatu sistem yang mendeteksi terjadinya penyimpangan kualitas ouput yang tidak sesuai dengan standar. Oleh sebab itu quality control memerlukan indikator kualitas yang jelas dan pasti. Berdasarkan tipologi madrasah/sekolah yang ada sehingga dapat ditentukan standar penyimpangan kualitas yang terjadi. Standar kualitas ini bersifat relatif dan dapat dicapai oleh setiap madrasah/sekolah. Standar kualitas digunakan sebagai tolok ukur untuk mengetahui maju mundurnya madrasah/sekolah

Model pendekatan di atas tidak hanya dapat diaplikasikan pada pendidikan lembaga saja, namun lebih pada itu juga sangat memungkinkan dilakukan pada sub-sub mata pelejaran dalam rangka penjaminan mutu dan kualitas peserta didik dalam beragam bidang kependidikan yang ditekuni guna mewujudkan mutu pendidikan secara holistik atau totalitas.

\section{BAB III \\ PENUTUP}

Dari uraian diatas dapat diambil kesimpulan

1. Konsep dasar manajemen mutu pendidikan memuat secara inklusif elemen-elemen sekolah efektif, yang dikategorikan menjadi input, proses, dan output

2. Peningkatan mutu pendidikan meliputi:
a) Kualitas output
b) Kualitas proses
c) Kualitas input
d) Kualitas instrumental input (pemasuk)

3. Prinsip manajemen mutu pendidikan meliputi beberapa aspek sebagai berikut:
a) Perencanaan
b) Pelaksanaan
c) Pengendalian'
d) Pengawasan
e) Pengukuran hasil
f) Pelayanan masyarakat
g) Pembinaan lingkungan

117| Model Pendekatan Peningkatan Mutu Pendidikan Agama Islam 
3. Pendidikan agama Islam yang berhasil perlu dilakukan pendidikan agama yang terpadu. Keterpaduan yang dimaksud adalah: keterpaduan tujuan, keterpaduan materi, dan keterpaduan proses

4. Faktor-faktor pendidikan agama dapat dikelompokkan menjadi lima macam. Antara lain : (1) peserta didik, (2) pendidik, (3) tujuan pendidikan, (4) alat-alat pendidikan, dan (5) lingkungan / millieu

5. Model pendekatan peningkatan mutu pendidikan agama islam antara lain Preliminary control, concurrent control, rework control dan damage control. Dari ke empat model pendekatan mutu pendidikan ini lebih ringkasnya mencakup input, transformasi (proses), output, dan stakeholder value ( nilai pengguna)

6. Model penjamin mutu Pendidikan Agama Islam, antara lain:school review, benchmarking, quality control, dan quality assurance

\section{DAFTAR RUJUKAN}

Alma, Buchari \& ratih Hurriyati. Manajemen Corporate dan Strategi Pemasaran Jasa Pendidikan. (bandung: Alfabeta, 2008)

Bafadal, Ibrahim. Manajemen Peningkatan Mutu Sekolah dasar (Jakarta: PT Bumi Aksara, 2006)

Hadis, Abdul dan Nurhayati. Manajemen Mutu Pendidikan ( Bandung; Alfabeta,2010)

Hanafiah, Nanang \& Cucu Suhana. Konsep Strategi pembelajaran. (Bandung: PT Refika Aditama, 2009)

Muhaimin. Pengembangan Kurikulum Pendidikan Agama Islam. ( Jakarta: PT RajaGrafindo Persada, 2010)

Rachman Abdul Shaleh. Madrasah dan Pendidikan Anak Bangsa. (Jakarta:PT RajaGrafindo Persada, 2006)

Rivai, Veitsal dan Sylviana Murni. Education Management ( Jakarta; PT Rajagrafindo, 2009)

Rusman. Manajemen kurikulum. (bandung:PT Rajagrafindo Persada, 2009)

Tafsir, A dalam www.scribd.com/.../STRATEGI-MENINGKATKAN-MUTU-PAI

Tim Pengembang ilmu Pendidikan FIP-UPI. Ilmu dan Aplikasi Pendidikan.

(Bandung: PT Imperial Bhakti utama, 2007)

Tim Dosen Administrasi pendidikan UPI. Manajemen Pendidikan. (Bandung: Alfabeta, 2009)

Usman, Husaini. Manajemen teori praktik dan riset pendidikan. (Jakarta:Bumi Aksara, 2008)

Zuhairini dan Abdul Ghofir. Metodologi pembelajaran Pendidikan Agama islam ( Malang: UM Pres, 2004)

www.kabar-pendidikan.blogspot.com 